\title{
Water balance and net radiation in forest and pasture area in Southwest Amazon
}

\author{
Balanço hídrico e saldo de radiação em área de floresta e pastagem no Sudoeste da Amazônia
}

\section{Camila Bermond Ruezzene', Denise Parizotto", Ana Carolina Cidin"', Dayane de Oliveira'v, Thandy Junio da Silva Pintov, Silvio Crestana ${ }^{\mathrm{VI}}$, Renato Billia de Mirandavil, Frederico Fábio Mauad ${ }^{\mathrm{vIII}}$}

\section{Abstract}

Energy availability has direct influence over hydrological cycle, climate and preciptation. The determination of net radiation balance $(\mathrm{Rn})$ and the spacial and temporal recognition of water availability allow establishing guidelines and planning the implementation of public resource management policies. The objective of this study was to analyze the water balance and net radiation balance of the year 2017 at two experimental sites in the state of Rondônia (RO), Brazil: an Amazon rainforest area located in the Jaru Biological Reserve (REBIO) and a pasture area (FNS) located in the municipality of Ouro Preto d'Oeste, near the forest área. The data were obtained from the REBIO climatological station, in the municipality of Ji-Paraná-RO, belonging to the experimental sites. Calculations for evapotranspiration potential were based on Thornthwaite and Mather's method. The "Eddy Covariance" method was used to obtain the radiation balance. The forest system presented greater energy availability in the rainy season and higher evapotranspiration balance when compared to the pasture area. Water balance extract analysis pointed to water stress in pasture area, opposite to the forest area, which indicates that conversion of native forest to pasture is a process capable to compromise the availability of water resources and alter climatic aspects.

Keywords: Evapotranspiration; Energy balance; Hydrological cycle

\section{Resumo}

A disponibilidade de energia tem influência direta no ciclo hidrológico, no clima e na precipitação. A determinação do saldo de radiação líquida $(\mathrm{Rn})$ e reconhecimento espacial e temporal da disponibilidade hídrica permitem estabelecer diretrizes e planejar a implementação de políticas públicas de gestão de recursos. O objetivo deste estudo foi analisar o balanço hídrico e saldo de radiação do ano de 2017, em dois sítios experimentais no estado de Rondônia: uma área de floresta tropical amazônica situada na Reserva Biológica do Jaru (REBIO) e uma área de pastagem (FNS) localizada no município de Ouro Preto d'Oeste, próxima a área florestal. Os dados foram obtidos da estação climatológica da REBIO, no município de Ji-Paraná, pertencente aos sítios experimentais. Os cálculos para o potencial de evapotranspiração basearam-se no método de Thornthwaite e Mather. Utilizou-se o método "Eddy Covariance" para obtenção do saldo de radiação. A área florestal apresentou maior disponibilidade de energia no sistema no período chuvoso e saldo de evapotranspiração superior à área de pastagem. A análise do extrato do balanço hídrico apontou estresse hídrico na área de pastagem, oposto da área florestal, indicando que a conversão de floresta nativa em pasto é um processo que pode comprometer a disponibilidade de recursos hídricos e alterar aspectos climáticos.

Palavras-chave: Evapotranspiração; Balanço de energia; Ciclo hidrológico

MSc Candidate of the Postgraduate Program in Environmental Engineering Sciences, Center for Water Resources and Environmental Studies, University of São Paulo, São Carlos, SP, Brazil - camila.ruezzene@gmail.com; deniseparizotto3@gmail.com

III, Iv, V PhD Candidate of the Postgraduate Program in Environmental Engineering Sciences, Center for Water Resources and Environmental Studies, University of São Paulo, São Carlos, SP, Brazil - carolcidin@gmail.com; thandyjuniosilva@usp.br; dayaolivei@gmail.com

PhD in Applied Physics, Postgraduate Program in Environmental Engineering Sciences Professor of University of São Paulo, Embrapa Instrumentation, São Carlos, SP, Brazil - silvio.crestana@embrapa.br

PhD in Environmental Engineering Sciences, Postgraduate Program in Environmental Engineering Sciences Professor of University of São Paulo, Center for Water Resources and Environmental Studies, University of São Paulo, São Carlos, SP, Brazil - rbm1706@gmail.com

VIII PhD in Energy Systems Planning, Postgraduate Program in Environmental Engineering Sciences Professor of University of São Paulo, Center for Water Resources and Environmental Studies, University of São Paulo, São Carlos, SP, Brazil - mauadffm@sc.usp.br 


\section{Introduction}

The Amazon rainforest resembles atmospheric conditions in remote marine regions (MARTIN et al., 2010; WILLIAMS et al., 2002; CHINA et al., 2018) and an important role in the maintenance of regional and global climate, directly influencing evapotranspiration, water vapor supply, and consequently the flow of water and energy as a whole (COHEN et al., 2007).

Consistent management of soil and water is fundamental for sustainability and resilience, so that these resources can be maintained over time with sufficient quantity and quality to maintain satisfactory levels of productivity (LOPES et al., 2004).

The spatial and temporal knowledge of water availability allows establishing guidelines and better agricultural planning, as well as the implementation of resource management policies (HORIKOSHI; FISCH, 2007; SANTOS et al., 2010).

Climatological hydric balance (BHC) is a tool to determine the water regime of a site, without the need for direct measurements of soil conditions. Passos, Zambrzycki, and Pereira (2017) consider BHC as an important tool in rural strategic planning for water resources management. $\mathrm{BHC}$ can be dominated in knowledge of water stress in crops and irrigation of agricultural areas (OLIVARES et al., 2018). Carvalho et al., (2010), explains that the elaboration of the $\mathrm{BHC}$ of a place or region is fundamental for characterization of the climate. Then, the water balance allows to classify the climate of a region, to manage the water resources, to present the environmental and agricultural zoning, the water availability or when in situation of scarcity (SANTOS; HERNANDEZ; ROSSETTI, 2010).

The net accounting of all radiant energy received and lost on the surface directly influences the determination of the hydrological cycle, the development of the boundary layer, the climate, and precipitation. According to
Andrade et al. (2009), the balance of radiation has a direct link with the hydrological cycle, making important the characterization and quantification of processes related to the energy balance, relevant for the formulation of environmental and climatic policies.

According to the Agrosilvopastoril Sanitary Defense Agency of the State of Rondônia (IDARON, 2008), Rondônia gained strength for the livestock sector and thus, the pasture areas expanded and consequently, the forest areas suffered damages (WEBLER, et al. 2013). Thus, the objective of this study was to analyze the annual water balance and radiation balance in two experimental sites in the state of Rondônia, a tropical forest area (REBIO) and a pasture area (FNS), through the energy potential, evapotranspiration potential, water deficiency or surplus, and total water retained in the soil.

\section{Materials and Methods}

This study was conducted at two experimental sites in the state of Rondônia, in a tropical forest area and another in a pasture area located at the experimental sites of the tower network of the Large Scale Biosphere-Atmosphere Program in the Amazon, LBA Program (figure 1).

The forest area is located in the Jaru Biological Reserve (REBIO Jaru), $10^{\circ} 11^{\prime} 11.4^{\prime \prime}$ 'S; $61^{\circ} 52$ '29.9 “W, this being a federal conservation unit of integral protection, created by Decree 83.716 of July 11, 1979, under the tutelage of the Chico Mendes Institute for Biodiversity Conservation (ICMBio). It is composed by the municipalities of Ji-Paraná, Vale do Anari and Machadinho do Oeste.

The vegetation is classified as Open Amberophilous Forest (CULF et al., 1997), possessing sub-forest of palm trees of a few meters, with a mean canopy height of 30 $\mathrm{m}$ and some emergent trees with approximately $45 \mathrm{~m}$ (RUMMEL et al., 2002).

Figure 1- Location of the Jaru Biological Reserve (REBIO) and Fazenda Nossa Senhora (FNS)

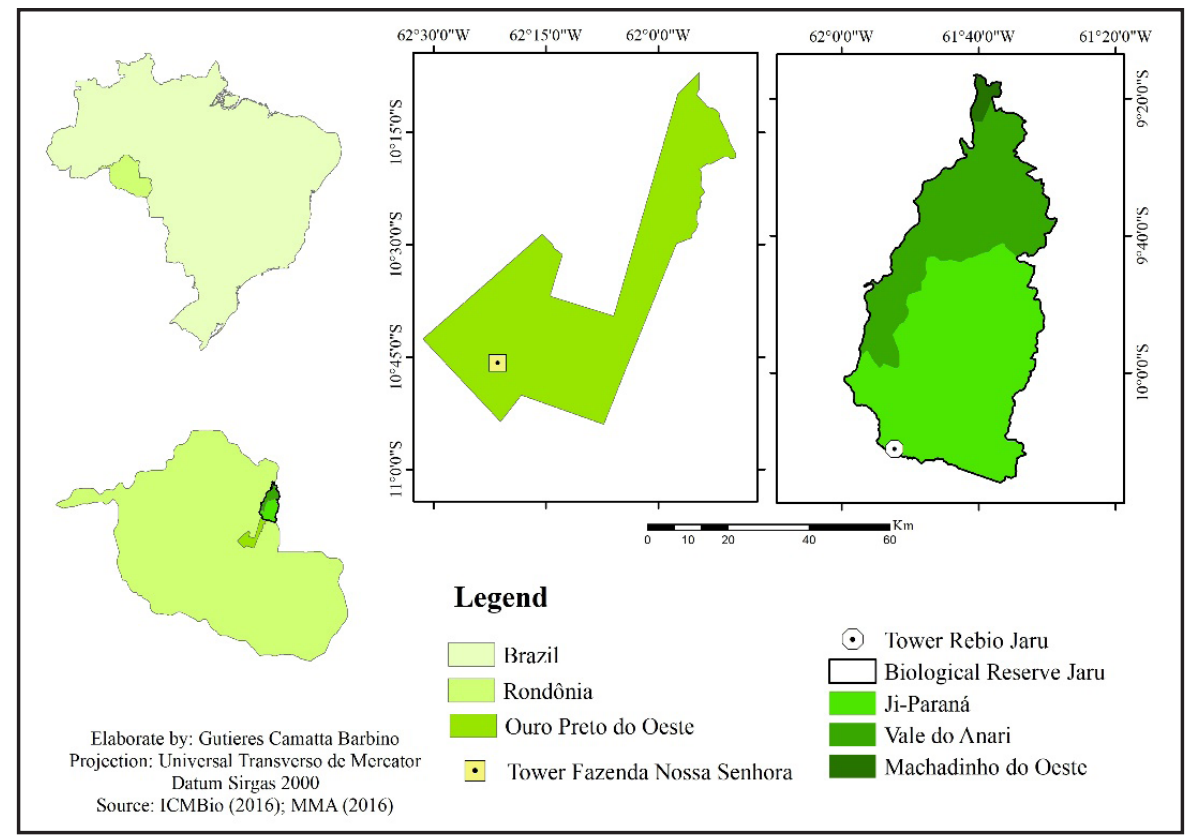


In the forest region there are two distinct types of soils, namely: Yellow Red Latosol and Yellow Red Argisol, the latter also known as Yellow Red Podzolic (BALLESTER et al., 2012). Most of the region is mainly composed of rainforest (Oliveira 2012).

Mean annual precipitation rates are over 2,000 mm (WEBLER et al., 2007) and mean annual temperature of $24^{\circ} \mathrm{C}$ in the rainy season and $25^{\circ} \mathrm{C}$ in the dry season (AGUIAR et al., 2006).

The Fazenda Nossa Senhora (FNS) $10^{\circ} 45^{\prime} 44^{\prime \prime} \mathrm{S}, 62^{\circ}$ $21^{\prime} 27^{\prime \prime} \mathrm{W}$, is located in the municipality of Ouro Preto, at an altitude of $220 \mathrm{~m}$ above sea level. The experimental site was deforested by burning in 1977 with an approximate radius of $50 \mathrm{~km}$, and since then it has been considered a homogeneous area with predominance of the grass cover of Brachiaria brizantha grass, besides some dispersed palm trees. The region is occupied by about $74 \%$ of pasture, $16 \%$ by secondary succession areas and the other $10 \%$ of rainforest (Oliveira 2012). The fetch at the experimental site is approximately $1-2 \mathrm{~km}$ in all directions (VON RANDOW et al., 2004).

The mean annual precipitation is $1627 \mathrm{~mm}$ and the mean air temperature is $24.8^{\circ} \mathrm{C}$, presenting period with more intense rains from January to March and dry period from July to September (WEBLER et al., 2013).

The soils of this region are classified as Argissolo (also known as Podzolic), ranging from Red Yellow to Red Yellow Dark (BALLESTER et al., 2012).

The region presents characteristic and well determined seasonal periods being subdivided in humid the period from January to March, wet-dry April to June, dry July to September and dry-wet October to December.

Therefore, data from the experimental sites were used to calculate the evapotranspiration, the water balance and the radiation balance $(\mathrm{Rn})$, with the relative air humidity (RH), air temperature and precipitation, for the year 2017. Measurements were performed using the HMP35A and HMP45C instruments (Vaisala Inc., FIN), installed 10 meters high at FNS and 62 meters at REBIO Jaru, RAG-100 rain gauge at $0.90 \mathrm{~m}$ and $61 \mathrm{~m}$ at FNS and REBIO, respectively. The radiation balance was measured by NR Lite 1 (Kipp \& Zonen, Delft, NLD). Measurements were performed every 30 seconds and averages every 10 minutes, which were later stored in a CR10X (Campbell Scientific Instrument, USA) datalogger.

\subsection{Hydric Balance}

In order to calculate the water balance, it is necessary to estimate the amount of evapotranspirated water in the crops, that is, evapotranspiration (ETP). The evapotranspiration represents the losses of water, in the atmospheric system and the relation of the processes of evaporation in the soil, humidity of the vegetation and transpiration of the plants. In this sense, the water balance was carried out based on the method of Thornthwaite and Mather (1955). This method is well used, for ease and consider only the average atmospheric temperature (CAMARGO; CAMARGO 2000).

The water balance can be determined through the inputs and outputs in the total system. Rainfall precipitation $(\mathrm{P})$, dew $(\mathrm{O})$, surface runoff $(\mathrm{Ri})$, subsurface runoff $(\mathrm{DLi})$, capillary rise $(\mathrm{CA})$ are considered as inputs. The outputs are evapotranspiration (ETP), surface runoff (Ro), subsurface runoff (DLo) and drainage (DP) (PEREIRA; ANGELOCCI; SENTELHAS, 2007).

Thus, the representation of the general equation of the water balance is given by:

$$
\Delta \mathbf{B h}=\mathbf{P}-\mathbf{E T P}-\mathbf{D P}
$$

In addition, the values of $150 \mathrm{~mm}$ for the forest area (REBIO) and $50 \mathrm{~mm}$ in the pasture area (FNS) were considered for the available water capacity (CAD). Evapotranspiration (ETP), accumulated negative (NE-AC), real evapotranspiration (ETR), water deficit (DEF), soil water change (ALT) and surplus (EXC) were calculated according to precipitation data.

The initial calculation was performed by P-ETP and then by ARM, NE-AC, ALT ETR and DEF. According to the conditions of the P-ETP $<0$ or P-ETP $>0$, the ways of calculating the ARM differ in two criteria (equations 2 and 4$)$.

$$
\begin{aligned}
& \mathrm{NE}-\mathrm{AC}=\mathrm{P}-\mathrm{ETP} \\
& \mathrm{ARM}=\mathrm{CAD} \mathrm{e}^{-\left|\frac{\mathrm{NE}-\mathrm{AC}}{\mathrm{CAD}}\right|}
\end{aligned}
$$

or

$$
\begin{aligned}
& \mathrm{ARM}=\mathrm{ARM} a+(\mathrm{P}-\mathrm{ETP}) \\
& \mathrm{ARM}=\mathrm{CAD} \ln ^{-\left|\frac{\mathrm{ARM}}{\mathrm{CAD}}\right|}
\end{aligned}
$$

Subsequently, the ALT was calculated by the following equation:

$$
A L T=A R M-A R M a
$$

Following the sequence, the ETR was calculated (equation 6 and 7), following criteria:

$$
(P-E T P)<0=E T P=P+(A L T)
$$

or

$$
(P-E T P) \geq 0=E T R=E T P)
$$

DEF was determined by the equation:

$$
D E F=E T P-E T R
$$

The determination of the water balance (equations 8 and 9) was finalized following two criteria (ARM $\angle C A D)$ and $(\mathrm{ARM}=\mathrm{CAD})$ with EXC:

$$
A R M<C A D=E X C=0
$$

or

$$
A R M=C A D=E X(P R E C-E T P)-A L T
$$




\subsection{Statistical Analysis}

In the statistical analysis of the data, the normality was verified by the Shapiro-Wilk test and the homogeneity of variances by the Levene test, when the data did not meet the precepts of the parametric statistic they were transformed and maintained the behavior, nevertheless, techniques were used of non-parametric statistics. The difference between the study areas (FNS and REBIO) for all analyzed parameters of energy balance and water balance was verified by Student's t-test, and the non-parametric alternative was the Mann-Whitney test.

\section{Results and Discussion}

\subsection{Radiation Balance}

Figure 2 shows the radiation balance of the Nossa Senhora-FNS farm (pasture area) and the Jarú-REBIO Biological Reserve (forest area).

It should be noted that for the months of March, April, July and August the data had a relative low performance (below $40 \%$ ). In the analysis of the figures it is observed that, in general, the data of net radiation for the REBIO are superior to those of the FNS, presenting statistically significant difference $(\mathrm{p}<0.01)$. These results were similar to those verified by Pavão et al. (2016), in a study of energy balance in forest areas in southern Amazonas. It was verified that in the forest area there is a greater availability of energy in the system in the rainy season, which can be used in surface heating, photosynthesis or in the water balance (BIUDES et al., 2015). Lower values of $\mathrm{Rn}$ in the pastures are rela- ted to the dry period and the burnings, as verified by Aguiar et al. (2006) and Webler et al. (2013). Gomes et al. (2015), who analyzed the data from the same area of this research, during the period from 1999 to 2010, stated that the pasture radiation balance was almost $20 \%$ lower compared to the forest.

Comparing the mean values of temperature between the two analyzed conditions (Figure 3), it can be observed that in the forest area the average monthly temperatures remain larger in relation to the pasture area, although there is no statistically significant difference ( $p>0.05)$.

This phenomenon can be attributed to thermal instability in the pastures, which allows a greater loss of heat during the night, decreasing the temperature averages, while in the forest the daily thermal variations are smaller, implying higher mean values. This hypothesis is reinforced by the higher values of net radiation obtained for REBIO. Aguiar et al. (2011) observed, in the same area of study, average temperatures, collected in 2005, well above those measured in this work.

\subsection{Hydric Balance}

Figures 4 and 5 present the normal water balance for the two study areas, with values of precipitation (Prec), potential evapotranspiration (ETP) and actual evapotranspiration (ETR).

Considering the annual precipitation, it is observed that the highest indices occur in the biological reserve for the rainy season (January to March), highlighting that for the month of February there is not a good use of the data for REBIO, therefore the low values should be disregarded. On the other hand, in the pasture area the transition periods present higher indices, although

Figure 2 - Balance of radiation for the REBIO and FNS in the year 2017

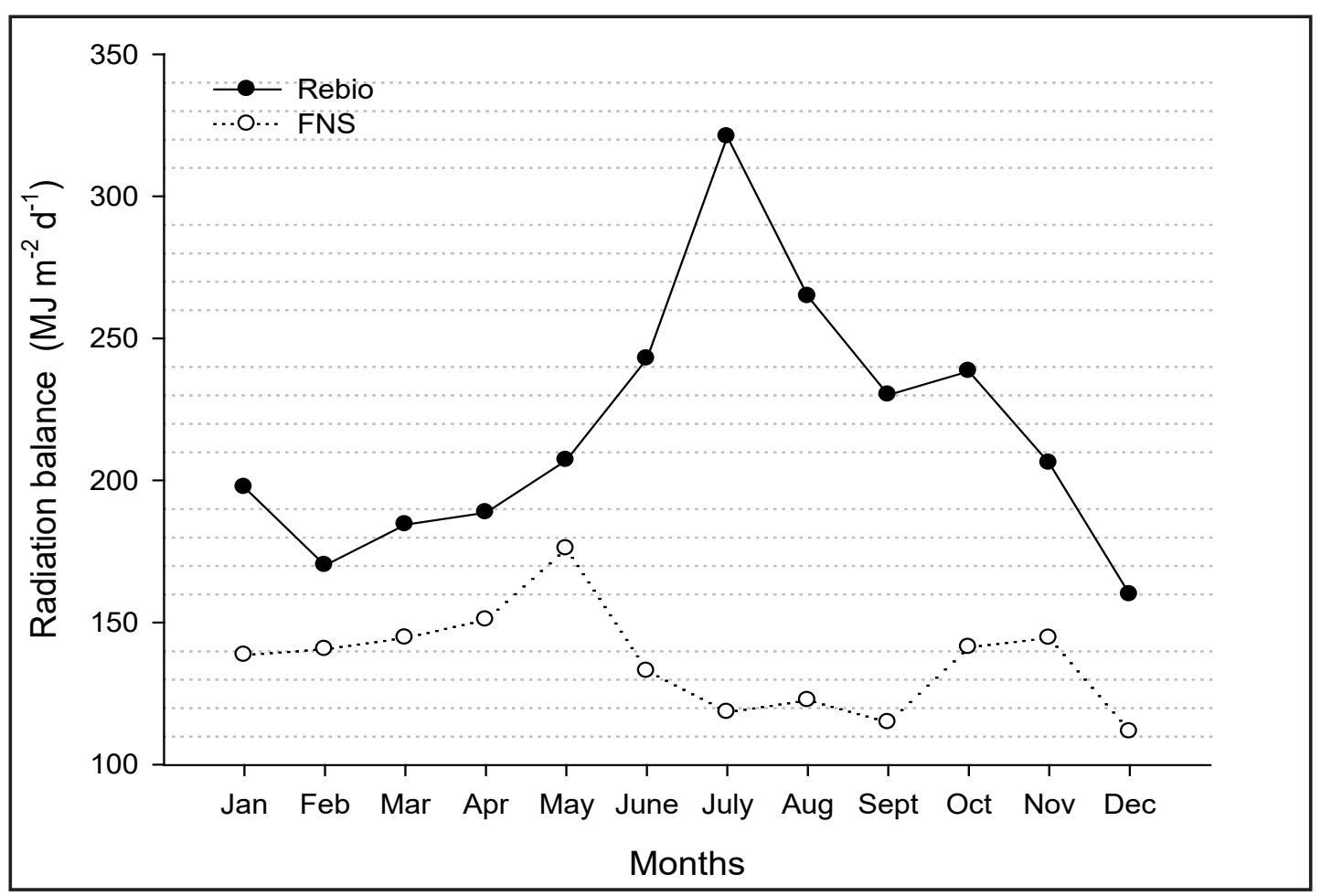


Figure 3 - Monthly mean temperature of REBIO and FNS

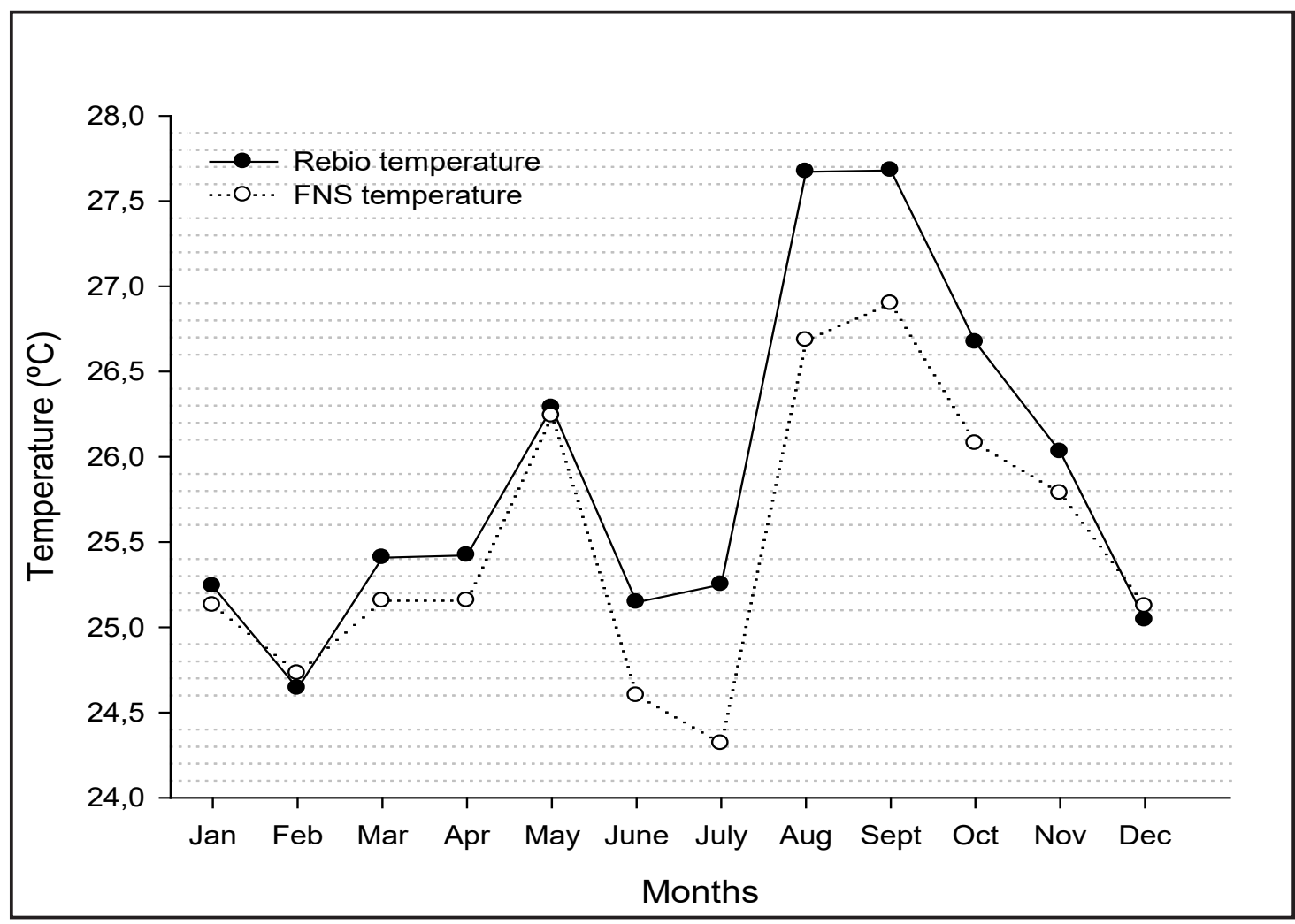

Figure 4 - Normal water balance of REBIO in the year 2017

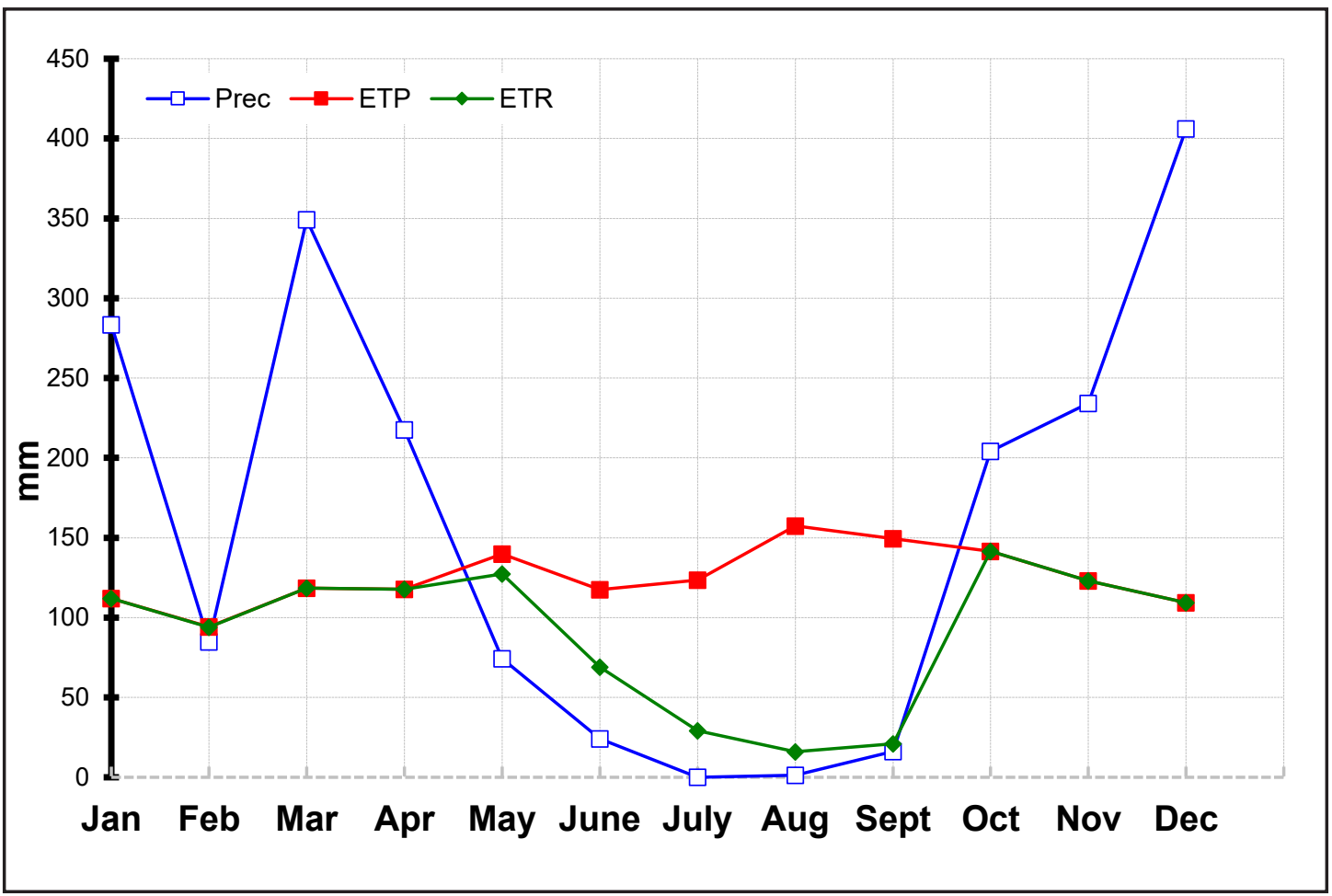


Figure 5 - Normal water balance for FNS in 2017

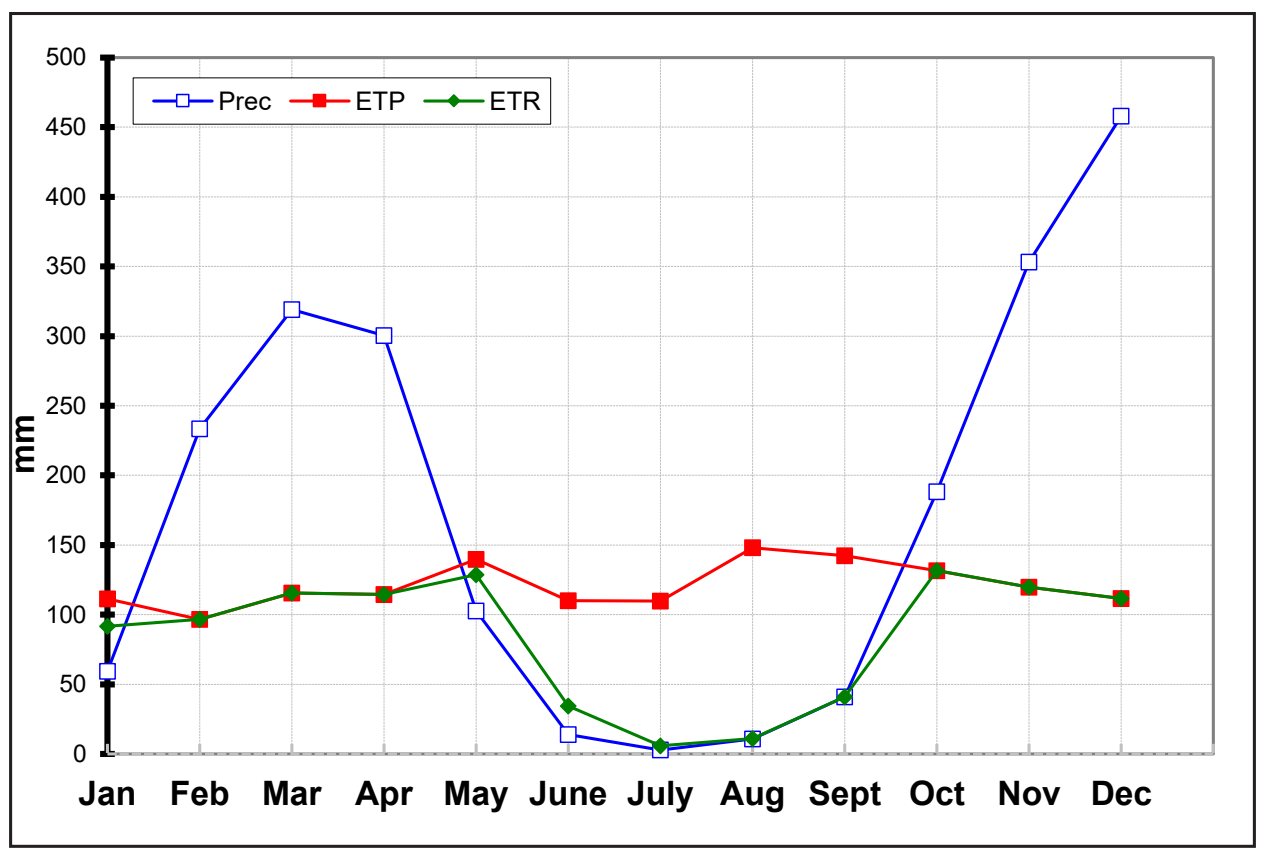

there is no significant statistical difference between the two locations for any of the periods of the year ( $p>$ $0.05)$. The dry period resembles between both areas. When the evapotranspiration balances are considered, it is observed that although the ETP values are similar for both areas, it can be observed that the forest ETP remained larger. This phenomenon occurs because the root system of the forest is deeper, as it is more likely to capture water and make it available to the atmosphere (NOBREGA et al., 2017).

For the data of water balance extract (Figures 6 and 7), it can be observed that for the rainy season the NSF presents higher surplus indexes, as well as, for the dry period, the REBIO presents major deficiencies. Howe- ver, it is noteworthy that the peak of the deficit of the stratum of the water balance in the forested area occurs after a longer prolongation of the dry period, while the highest indexes for grazing occur after a shorter period after the end of the rainy season (January with longer rainfall and dry transition periods, with the highest peaks recorded in the month of August for both locations. This process indicates that, although the dry period seems to be more severe in the forest area, this phenomenon has a lower frequency of occurrence, implying that the pasture area presents a greater prolongation of water stress (NOBREGA et al., 2017).

Another point to highlight is the occurrence of surpluses. For the pasture area the onset of rainfall is already

Figure 6 - Extract of the water balance of the FNS in the year 2017

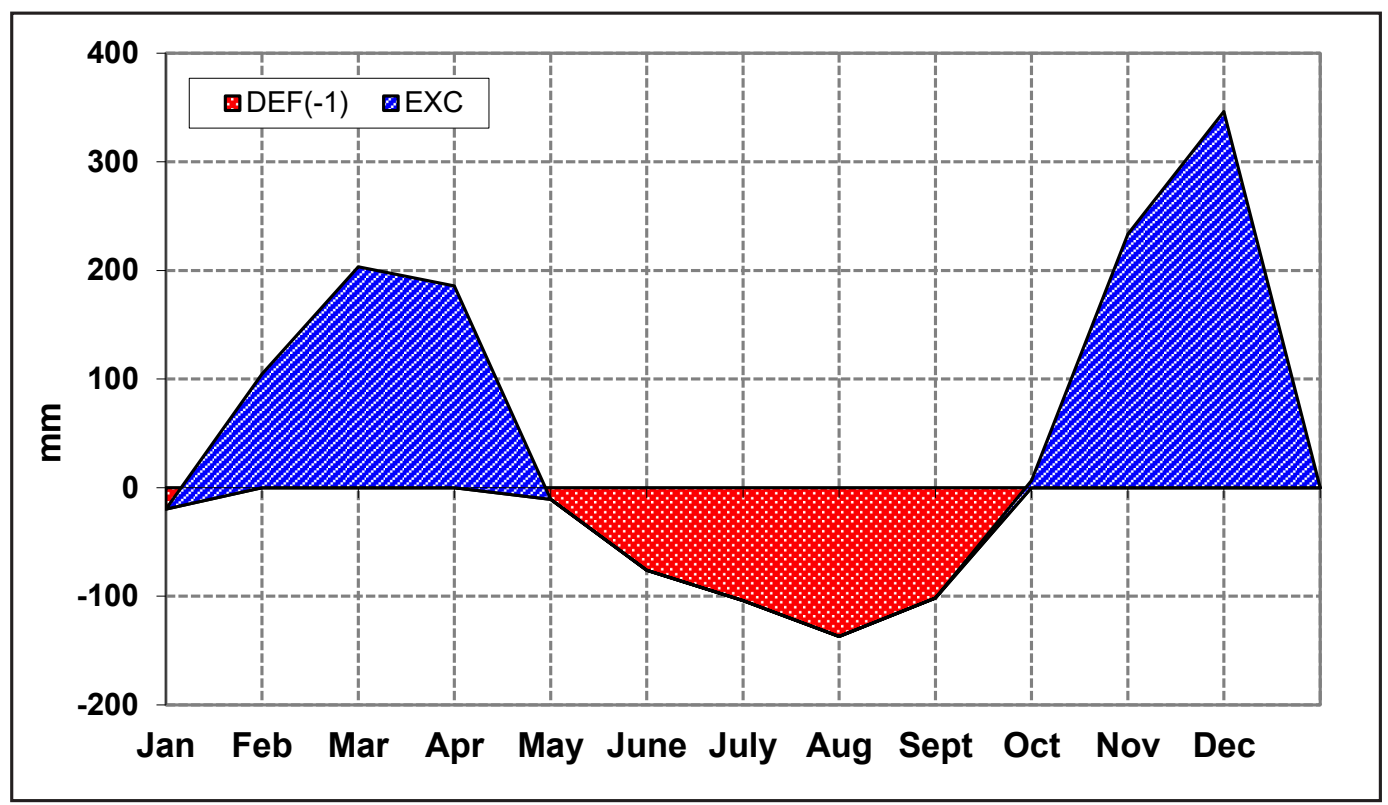


Figure 7 - Extract of the water balance in REBIO in the year 2017

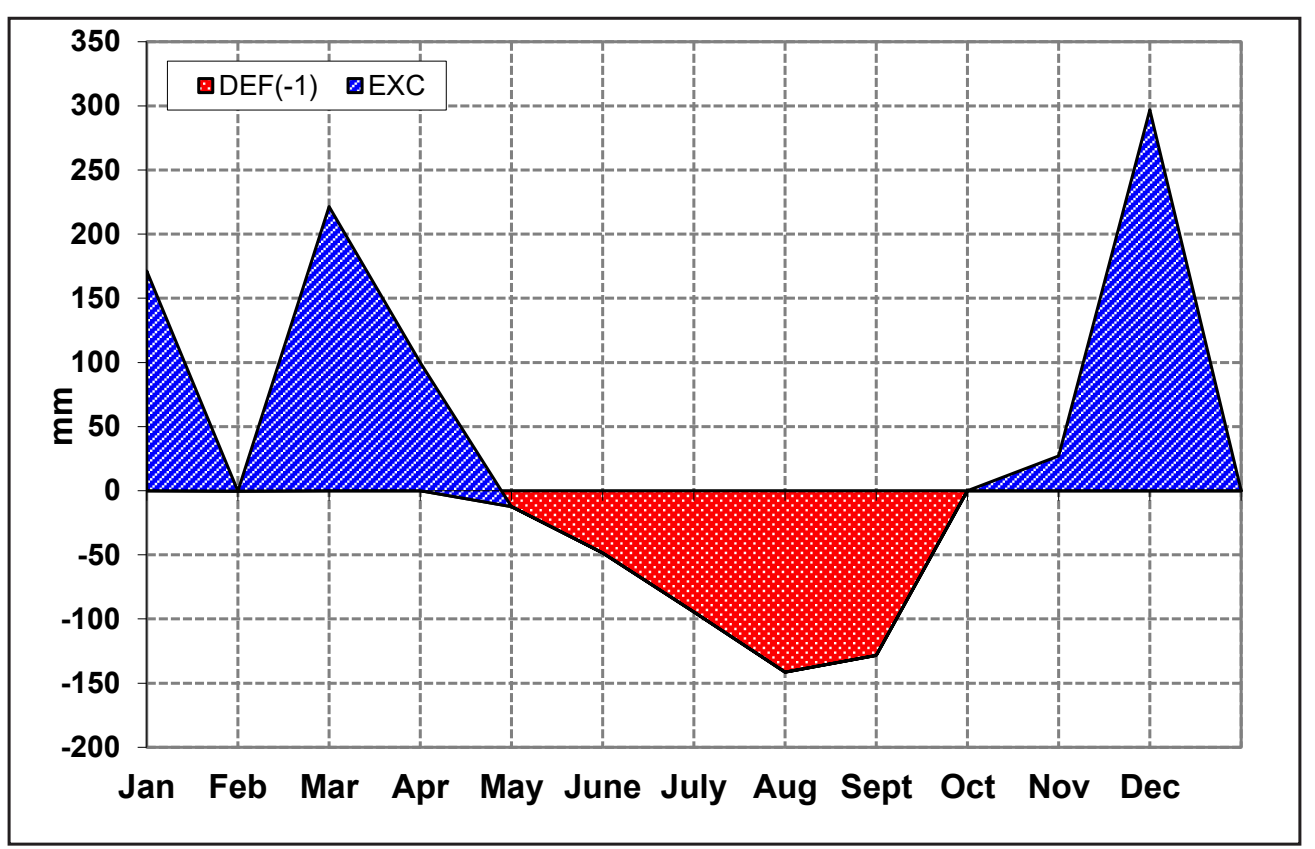

marked by a higher index of occurrence of surpluses, whereas for the forest, this phenomenon occurs after the second month of the beginning of the dry-rain transition period. This behavior can be attributed to two phenomena, the first one due to the greatest water deficiencies occurring in the forest at the end of the dry season, and the second due to the greater climatic stability of the forested area, implying a lower water loss to the atmosphere in the rainy season, with consequent increase of water retention in the soil. It should be noted that the month of February should be disregarded due to the low utilization of the data.

Figures 8 and 9 represent the precipitation destination (replacement, withdrawal, deficiency, and surplus).
In their analysis, the findings discussed above can be better understood.

When the withdrawal values are observed for both areas, it is possible to observe that in the forest area the highest indices occur, confirmed by the higher rates of actual evapotranspiration, implying a greater availability of water to the atmosphere, as observed in the humidity data relative to air (Figure 8), and greater prolongation of the period for the occurrence of higher values of deficiency. Considering the beginning of the rainy season in the FNS, it is noticed that only in the month of October occurs the water replacement, being observed deficiency and water withdrawal already in January with a new need for replacement for the month of February,

Figure 8 - Deficiency, surplus, withdrawal and replenishment of precipitation in the FNS in the year 2017

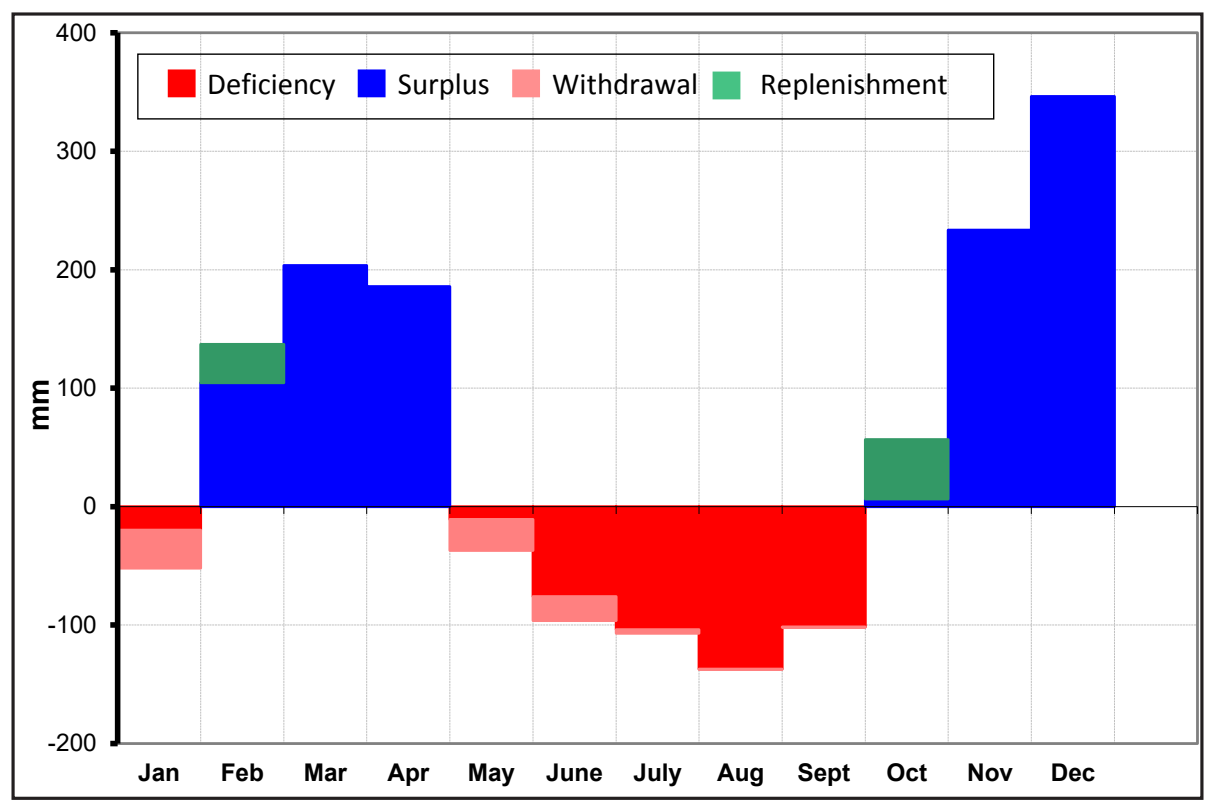


Figure 9 - Deficiency, surplus, withdrawal and replacement for REBIO in the year 2017

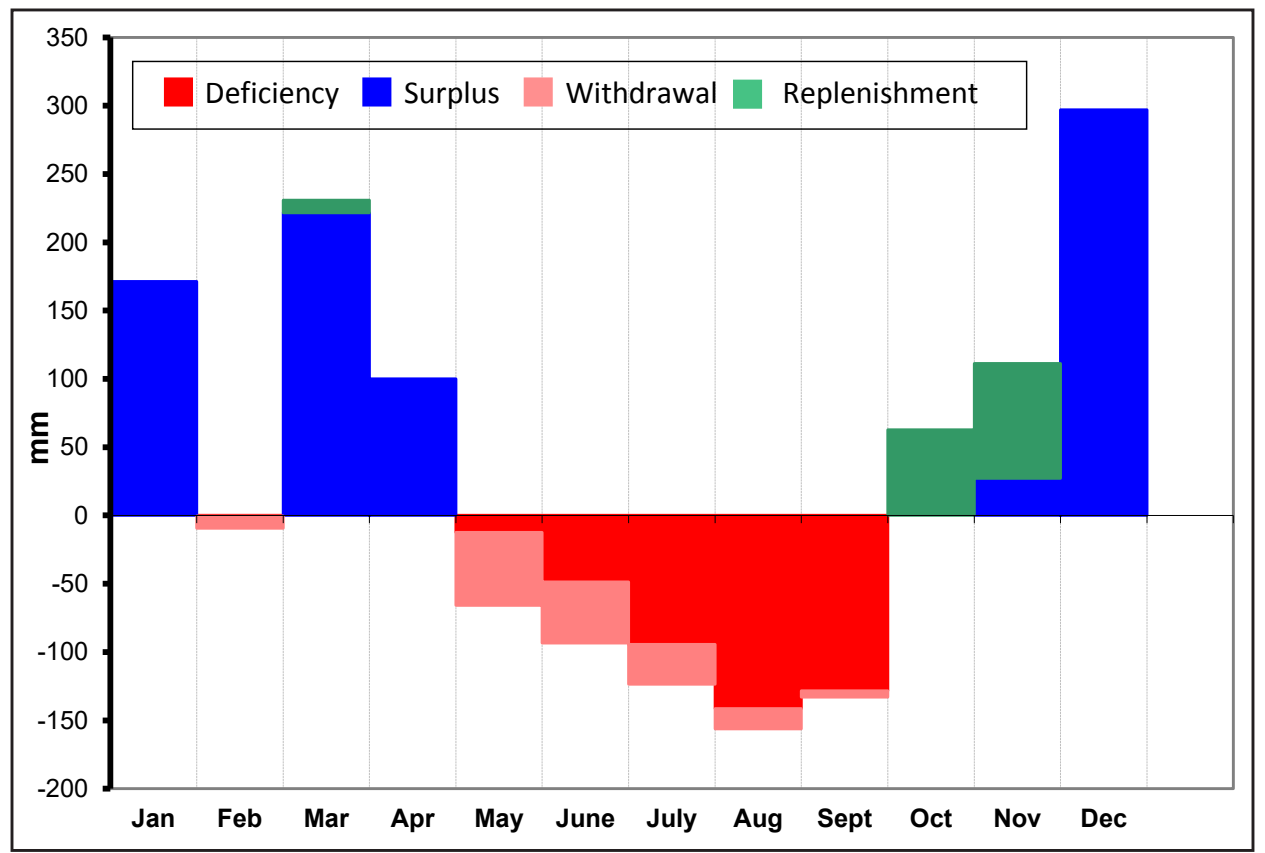

indicating a lower capacity in this area. Meanwhile, the months of October and November are characterized by being REBIO replacement, indicating a greater capacity of water retention in this system. In addition, it is not observed the necessity of water withdrawal in the rainy season, it should be noted that the month of February should be disregarded due to the lack of sufficient data for the analysis. This behavior indicates the ability of the forest to retain water, which will be used in the period of deficiency bringing greater stability.

Relative humidity varied according to the season, when wetter months corresponded to the period with the highest water availability (January to April and October to December) and the driest to the rainfall period (June to September).

Figure 10 shows the relative humidity values of the air throughout the year for the two locations. It is possible to observe that during the year the values registered for the REBIO are higher than the verified for the FNS. This behavior may be related, as previously discussed, to the greater capacity of the forest root system to obtain water and, through evapotranspiration, to provide a greater amount of moisture to the atmosphere, a finding confirmed by the higher values of radiation balance in the forest.

Figure 10 - Monthly mean relative humidity of REBIO and FNS

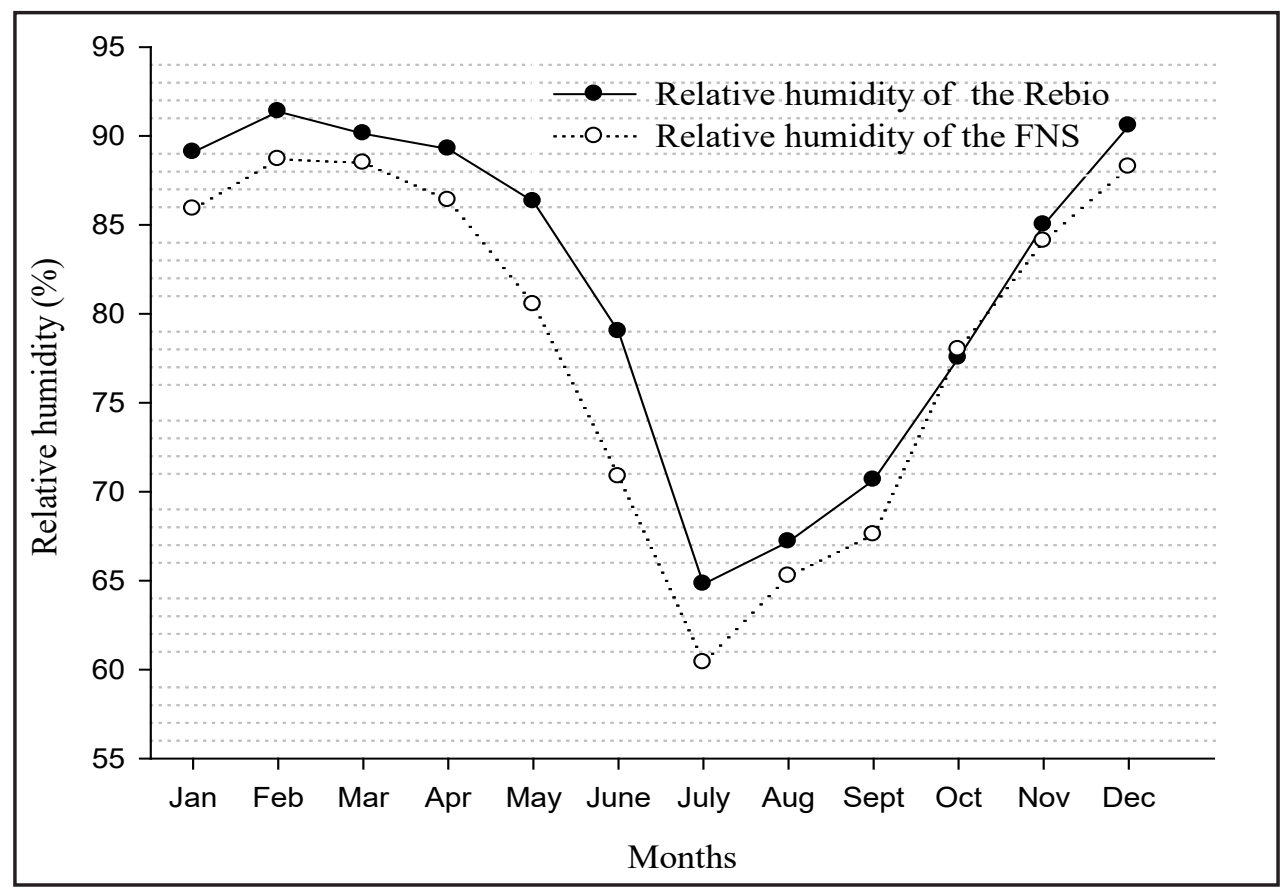




\section{Conclusions}

Forest area presented higher values of net radiation, greater energy availability in the rainy season and higher average temperatures, in comparison to the pasture area.

Considering annual precipitation, the highest indices occurred in the forest area from January to March. Regarding the evapotranspiration balance, it was observed that in the forest area this parameter was higher and the pasture area presented greater prolongation of the water stress.

According to this study, the conversion process of Amazonian native forest to pasture areas can lead to environmental impacts, indicating that physical changes such as vegetation cover destruction and soil disruption, as well as other aspects of this process, are likely to affect water resources availability, in addition to change local climate.

\section{Acknowledgments}

We thank the Large Scale Biosphere-Atmosphere Program in the Amazon for data availability. As, Coordination of Improvement of Higher Education Personnel (CAPES) and National Council of Scientific and Technological Development (CNPq).

\section{References}

AGUIAR, L.J.G. et al. Estimativa da radiação de onda longa atmosférica em áreas de floresta e de pastagem no sudoeste da Amazônia. Revista Brasileira de Meteorologia, v.26, n.2, p. 215-224, 2011.

AGUIAR, R.G. et al. Fluxos de massa e energia em uma floresta tropical no sudoeste da Amazônia. Revista Brasileira de Meteorologia, v. 21, n. 3b, p. 248-257, 2006.

ANDRADE, Nara Luisa Reis de et al. Partição do saldo de radiação em áreas de floresta amazônica e floresta de transição Amazônia - cerrado. Revista Brasileira de Meteorologia, [s.1.], v. 24, n. 3, p.346-355, set. 2009. FapUNIFESP (SciELO). http://dx.doi.org/10.1590/s010277862009000300008.

ANTONUCCI, B. et al. Fluxos de CO2 em uma área de floresta tropical úmida na Amazônia ocidental em um ano de el niño. Ciência e Natura, v. 40, p. 119-125, 2018.

BALLESTER, M.V.R.D. de C. et al. Soil Classification Map, Ji-Parana River Basin, Rondonia, Brazil. Tennessee: Oak Ridge National Laboratory Distributed Active Archive Center, 2012. LBA-ECO CD-06. Disponível em:< http://dx.doi. org/10.3334/ORNLDAAC/1088>. Acesso em: 05 de jul. 2018.
BIUDES, M.S. et al. Patterns of energy exchange for tropical ecosystems across a climate gradiente in Mato Grosso, Brazil. Agricultural and Forest Meteorology, v. 202, p. 112-124, 2015.

CAMARGO, A.P.; CAMARGO, M. B. P. Uma revisão analítica da evapotranspiração potencial. Bragantia. Campinas, v.59, n.2, p. 125-137, 2000.

CARVALHO, G. L. et al. Multivariate geostatistical application for climate characterization of Minas Gerais State, Brazil. Theoretical and Applied Climatology. v. 102. p. $417-428,2010$

COHEN, Julia Clarinda Paiva et al. Influência do desmatamento sobre o ciclo hidrológico na Amazônia. Ciencia e Cultura, São Paulo, v. 59, n. 3, p. 36-39, Sept. 2007. Available from <http:// cienciaecultura.bvs.br/scielo.php?script $=$ sci_ arttext\&pid=S000967252007000300015\&lng=en\&nrm=iso>. access on 14 Ago. 2018.

CULF, A.D. et al. The influence of the atmospheric boundary layer on carbon dioxide concentrations over a tropical forest. Agricultural and Forest Meteorology, v. 85, n. 3, p. 149-158, 1997.

CHINA, S. et al. Fungal spores as a source of sodium salt particles in the Amazon basin. Nature Communications. (9), p. 1-9, 2018. DOI: 10.1038/s41467-018-07066-4.

HORIKOSHI, A. S.; FISCH, G. Balanço hídrico atual e simulações para cenários climáticos futuros no Município de Taubaté, SP, Brasil. Ambi-Agua, Taubaté, v. 2, n. 2, p. 33-46, 2007.

IDARON - AGÊNCIA DE DEFESA SANITÁRIA AGROSILVOPASTORIL DO ESTADO DE RONDÔNIA. Informativo técnico do rebanho bovino de Rondônia. Porto Velho: IDARON, 2008.2p.

LOPES, Adriano S. et al. Manejo da irrigação (tensiometria e balanço hídrico climatológico) para a cultura do feijoeiro em sistemas de cultivo direto e convencional. Engenharia Agrícola, [s.1.], v. 24, n. 1, p.89-100, abr. 2004. FapUNIFESP (SciELO). http://dx.doi. org/10.1590/s0100-69162004000100011.

MARTIN, S. T. et al. Sources and properties of Amazonian aerosol particles. Rev. Geophys. 48, RG2002 (2010).

NÓBREGA, R.L.B. et al. Effects of conersion of native cerrado vegetation to pasture on soil hydro-phisycal properties, evapotranspiration and streamflow om te Amazonia agricultural frontier. PLoSONE, v. 12, n. 6, 2017. doi.org/10.1371/journal.pone.0179414. 
OLIVARES, O. B. et al. Analysis of climate types: Main strategies for sustainable decisions in agricultural areas of Carabobo, Venezuela. Scientia Agropecuaria. v. 9, n.3. p. 359-369, 2018.

Oliveira, G. 2012. Modelagem do balanço de energia e evapotranspiração na Amazônia Brasileira com uso de imagens MODIS E ASTER. Dissertação de Mestrado, Instituto Nacional de Pesquisas Espaciais, São José dos Campos, São Paulo. 227 pp.

PAVÃO, V.M. et al. Variação espacial e temporal do saldo de radiação superficial em uma área do sul do Amazonas, Brasil. Ra'e Ga, Curitiba, v.37, p.333 - 352, 2016.

PASSOS, V. L.M.; ZAMBRZYCKI, G. C.; PEREIRA, S. R. BALANÇO HÍDRICO CLIMATOLÓGICO E CLASSIFICAÇÃ̃O CLIMÁTICA PARA O MUNICÍPIO DE BALSAS-MA. Scientia Agraria. v. 8, p. 89-89, 2017.

PEREIRA, A.R.; ANGELOCCI, L.R.; SENTELHAS, P. C. Meteorologia Agrícola. Edição Revista e Ampliada. Piracicaba: Escola Superior de Agricultura "Luiz de Queiroz" - USP. Piracicaba, 2007. 125 p.

RUMMEL, U. et al. Eddy covariance measurements of nitric oxide flux within an Amazonian rain forest. Journal of Geophysical Research, v. 107, p. 1-9. 2002.

SANTOS, G. O.; HERNANDEZ, F. B.T.; ROSSETTI, J. C. Balanço hídrico como ferramenta ao planejamento agropecuário para a região de Marinópolis, noroeste do estado de São Paulo. Revista Brasileira de Agricultura Irrigada, v.4(3): 142-149, 2010

THORNTHWAITE, C.W.; MATHER, J.R. The water balance. Publications in climatology, New Jersey: Drexel Institute of technology, 1955.104p

VON RANDOW, C. et al. Comparative measurements and seasonal variations in energy and carbon exchange over forest and pasture in South West Amazonia. Theoretical and Applied Climatology, v, 78, p. 5-26. 2004.

WEBlER, A.D.; AGUiAR, R.G.; AGUiAR, L. J. G. Características da precipitação em área de floresta primária e área de pastagem no Estado de Rondônia. Revista Ciência e Natura, v. esp., p. 55-8, 2007.

WEBLER. A. D. et al. Mudanças no uso da terra e o particionamento de energia no sudoeste da Amazônia. Revista Brasileira de Engenharia Agrícola e Ambiental, v. 17, p. 868-876, 2013.

WILLIAMS, E. et al. Contrasting convective regimes over the Amazon: implications for cloud electrification. J. Geophys. Res. Atmos. 107, 8082 (2002). 